\title{
СОЦІАЛЬНА ВІДПОВІДАЛЬНІСТЬ РЕКЛАМИ
}

\author{
Данілова Л. Л. \\ к.е.н., доцент \\ кафедра маркетингу \\ Київський національний торговельно-економічний університет, \\ Украӥна
}

Ключові слова: соціальна реклама, суспільна роль реклами, психологічна роль реклами, політичної реклами, ідеологічна роль реклами, освітня роль реклами.

Keywords: social advertising, public role of advertising, psychological role of advertising, political advertising, ideological role of advertising, educational role of advertising.

Роль реклами у сучасному суспільстві вже давно не обмежується ані рамками комерційних комунікацій, ані навіть усією ринковою діяльністю. Значення реклами зростає у всіх галузях економіки та громадського життя.

Суспільна роль полягає в тому, що реклама впливає не лише на формування купівельних переваг, а й на становлення певних стандартів мислення й соціальної поведінки різних верств населення в кожній країні i в світі в цілому. Реклама стає частиною соціального середовища, і у певній мірі його відображенням.

Тісно пов'язана із соціальним значенням реклами іï психологічна роль, оскільки психологічна атмосфера в суспільстві і психологічний стан кожного окремого члена соціуму впливає на процеси, що відбуваються в суспільстві та напрямки його розвитку.

Вплив реклами на соціум важко переоцінити. В наш час оцінка цього впливу стає предметом гострої полеміки. В умовах демократії, що постійно розвивається, у розвинених країнах зростає роль політичної реклами, як засобу боротьби за голоси виборців. Саме рівень i професіоналізм політичної реклами, як засобу боротьби за виборчі голоси, значною мірою впливає на розклад політичних сил у країнах після кожних виборів.

Тісно пов'язана 3 політичною ідеологічна роль реклами. I це не дивно, тому що в сучасному суспільстві реклама стає одним із найважливіших факторів формування світогляду людини. Так, можна навести чисельні приклади того, яке місце посідала реклама у зміцненні і поширенні комуністичної ідеології в Радянському Союзі. 
Не можна не відзначити значну освітню роль реклами. Так, в процесі впровадження на ринок нових прогресивних товарів і технологій вона сприяє поширенню знань із різних сфер людської діяльності, прищеплює споживачам певні практичні навички.

В сучасній рекламі часто ілюструються історичні події, реклама іноді знайомить нас з побутом та звичаями різних соціальних груп та навіть країн, розповідає про досягнення вчених, знайомить 3 творчістю відомих художників, поетів і письменників.

Але освітня роль реклами не обмежується лише позитивним впливом, розглядаючи рекламу, як своєрідного «вчителя», слід нагадати про те, що вчителі бувають різними. У цьому аспекті реклама може навчити не лише правильно чистити зуби, але й змальовує безліч безглуздих способів їх втратити. Так, негативною в освітньому розумінні є реклама, яка, зображуючи небезпечні дії, вчить на ходу застрибувати на потяг, охолоджувати чашку з кавою, їдучи верхи на мотоциклі.

Зображення у рекламі небезпечних моделей поведінки становить загрозу для життя людей, оскільки такі «оригінальні дії» часто копіюються дітьми та підлітками, що призводить до негативних, а іноді і трагічних наслідків. Тому транслювання такої реклами не бажане взагалі, і вимагає супроводження застережень щодо небезпечності наслідування таких дій. Крім того, іноді рекламні повідомлення містять граматичні помилки, некоректне висвітлення певних явищ і подій (відсутність холестерину в соняшникової олії «Олейна»), що в свою чергу сприяє зниженню культурно-освітнього рівня суспільства.

Повна оцінка значення реклами у сучасному суспільстві наближується до реальної лише за умов відведення важливого місця її культурної ролі. Кращим зразкам рекламних звернень, починаючи зі стародавніх часів до сьогодення, можна цілком справедливо присвоїти статус творів прикладного мистецтва.

Соціально-економічні процеси, які відбуваються під впливом реклами вимагають усвідомлення суб'єктами рекламної діяльності міри своєї соціальної відповідальності.

Соціальний вплив реклами на суспільство полягає у здатності реклами впливати на стиль життя людей, встановлення пріоритетів, моделей поведінки, смаків, вподобань. 
Проте суб' єктам рекламної діяльності не слід забувати, що вони також є членами суспільства, і рекламований товар, який вони виводять на ринок, доведеться споживати і їм самим, і членам їх родин.

Важливий блок проблем становлять «культурні стереотипи» які нав'язуються рекламою. Так, якщо за часів радянського союзу, за відсутності комерційної реклами, прийнято було цитувати видатних письменників та поетів, героїв кінофільмів, героїв п’єс - як джерело культурної інформації, то в наш час спостерігається ситуація коли новими культурними орієнтирами стають «герої» рекламних сюжетів. Особливо діти і підлітки замість Пушкіна напам'ять цитують рекламні тексти і слогани.

Проблема полягає в самих образах наслідування, які пропонує сучасна реклама, добре, якщо рекламні повідомлення виховують патріотизм або зображують національних героїв. Але, нажаль, в сучасній рекламі все частіше використовуються сцени насилля, непристойні жарти і натяки і неприпустимі з точки зору культурних норм моделі поведінки.

\section{Список використаних джерел}

1. Бернет Дж. Маркетинговые коммуникации. Интегрированный подход / Дж. Бернет, С. Мориарти ; пер. с англ. Н. Габенов, В. Кузин. - СПб. и др. : Питер, 2011. - 545 с.

2. ГудымаЭ. Makeyourbrandvisibleagain: Как не тратить маркетингове бюджеты попусту / Э. Гудыма [Електронний ресурс]. - Режим доступу : http://mmr.ua/show/make_your_brand_visible_again_ remarketing_2018

3. Джоунс Дж. Роль рекламы в создании сильных брендов / Дж. Джоунс. - М. : Изд-во Вильямс ИД. - 2005. - 235 с.

4. Ромат Е. Реклама : учеб. для вузов / Е. Ромат, Д. Сендеров. 8-е изд. - СПб. : Питер, 2013. - 512 с. - (Стандарт третьего поколения).

5. Соціальна відповідальність українського бізнесу: результати опитування [Електроний ресурс]. - Режим доступу : http://pmguinfo. dp.ua/images/documents/korp_otnosheniya/soc_otvetstv.pdf 